Www.jmscr.igmpublication.org

Impact Factor 5.244

Index Copernicus Value: 83.27

ISSN (e)-2347-176x ISSN (p) 2455-0450

crossref DOI: _https://dx.doi.org/10.18535/jmscr/v4i11.72

Journal Of Medical Science And Clinical Research

\title{
Research of Alteration Minerals and Its Impact on the Environment around the Tehoru Hot Springs, Central of Moluccas
}

\author{
Author \\ Helda Andayany \\ Geophysics Laboratory-Department of Physics University of Pattimura, \\ PO Box 97233 Ambon, Mollucas Indonesia \\ Corresponding Author \\ Helda Andayany \\ Email: heldaandayany2014@gmail.com, Telp: +6285243676567
}

\begin{abstract}
Research was conducted to identify the rocks that were taken in and around the Tehoru hot springs, Central Maluku regency. The rock samples were analyzed using petrography. The results of sample analysis identifies a sinter travertine deposition dominated by the presence of the mineral calcium carbonate ( $\mathrm{CaCO} 3)$ or calcite in the area around the Tehoru hot springs. Petrographic analysis shows that calcite incision initially preparing amorphous precipitated sinter travertine has been transformed into a microcrystalline calcite size is less than $0.01 \mathrm{~mm}$. The sinter travertine also contains several other minerals were observed through an incision petrographic, ie anhydrite, iron oxides and quartz fragments. The deposition of sinter travelin form of mineral calcium carbonate or calcite, which is dominant around the Tehoru hot springs leave a good impact on the health of which is to improve the performance and efficiency of the body for its users, as a supplier of stimuli nerve from one cell to another and can kill certain germs or bacteria that attack the skin. In addition, sediment sinter travelin soluble in water will soon be absorbed by the roots of plants, because these substances are necessary for plant growth to be around the hot springs.

Keywords: alteration minerals, petrography, travelin sinter, calcium carbonate.
\end{abstract}

\section{INTRODUCTION}

The astronomical District of Tehoru located between 3.081589 to 3.41473515 South Latitude and Longitude 129.324649 to 129.915857 East, with an area of $534.22 \mathrm{~km}^{2}$. Establishment of a geothermal system area thought to be related to tectonic activity strong result from plate collision Ceram with plate Continent Australia (plate collision) that trigger the formation of intrusive rocks at depth as a heat source (heat sources) on the geothermal system Tehoru (Tjokrosapoetro,
2003). The in situ measurements in the Tehoru Hot Springs area obtained hot water $\mathrm{pH}$ of 6.9 and the electrical conductivity of $10,362-13,452 \mu \mathrm{s} / \mathrm{m}$. Besides the hot water temperature measured at the surface ranged between $90.4^{\circ} \mathrm{C}$. Given the measured surface temperature is high enough, it can be presumed that the mineral around the Tehoru hot springs already experienced changes of minerals or the host rock. Fluid flow either remaining solvent magma, water and gases through the media or fracture in the earth's crust, 
interacts with surrounding rocks, producing minerals change either in the process or substitution reaction constituent elements. Petrographic method be used to describe the texture of rocks to know the types of origin of rock and alteration processes that Occurs in rocks. Petrographic method is supported by XRD method with bulk analysis (analysis of powder and clay analysis). XRD analysis results, a pattern that could explain the presence of alteration minerals deposits in the study area. In addition, the rock samples were Analyzed Also using petrographic, so it can be spread and characteristics of alteration of rocks on the surface of the hot springs Tehoru. By mapping the alteration of rocks, it can be seen characteristics of the geothermal fluid in the reservoir, and what happens when the fluid flow to the surface.

\section{PREVIOUS STUDY}

The alteration hydrothermal rocks can be formed as narrow zones of up wide because it depends on the level of the parent rock permeability passed hydrothermal fluid. Because it involves temperature, pressure, type of rock origin, rock permeability, the length of hydrothermal activity, and most importantly, the composition of hydrothermal fluids, then the reaction of physicalchemical that occurs it is possible to produce a variety of mineral alteration, including the following: (1) in the mineralized rock by process alteration hydrothermal minerals contain detectable concentrations of certain elements of the land. For example, the product of alteration hydrothermal minerals both calcite and dolomite can contain anomalous pattern of these elements; Barite can contain a range width ratio of $\mathrm{Eu}$ (Europium) / Sm (samarium) (Moller DRR., 1979); while the quartz veins and quartzcarbonate-tourmaline can contain $\mathrm{Eu}$ anomaly with a flat pattern of distribution of REE (Kerrich and Fryer, 1979). Barite has a large ratio range of $\mathrm{Eu} / \mathrm{Sm}$ even positive Eu anomalies as a result of the substitution of the Ba (Morgan and Wandless, 1980); whereas chemical sediments associated with volcanic activity contains positive $\mathrm{Eu}$ anomalies and relatively large ratio of $\mathrm{Eu} / \mathrm{Sm}$; (2) hydrothermal system involving granitic magma can produce alteration mineral of the halide group (eg, fluorite) containing REE, Y and $\mathrm{Ce}$; of the carbonate group with fluoride in the form of bastnasite $[(\mathrm{Ce}, \mathrm{La})(\mathrm{CO} 3) \mathrm{F}]$; of oxide on the contact group metasomatik be pyroklor [A2B2O6 $(\mathrm{O}, \mathrm{OH}, \mathrm{F})]$ in this case A containing atoms of $\mathrm{Na}, \mathrm{Ce}, \mathrm{REE}, \mathrm{K}, \mathrm{U}$ and others; $\mathrm{B}$ containing $\mathrm{Nb}$, Ta and Ti (Henderson, 1982); (3) rocks are altered (eg barite-dolomite) associated with bastnasite and parisit [(Ce, La) $2 \mathrm{Ca}(\mathrm{CO} 3)$ $3 \mathrm{~F} 2$ ] can contain any of the mineral group of carbonate in the form of sahamalit $[(\mathrm{Mg}, \mathrm{Fe})(\mathrm{Ce}$, La) 2 (CO3) 4] (Jaffe DRR., 1953; Fleischer, 1978a); (4) Mineral oxide group in the form of cerianit [(Ce 4+, Th) O2] resulting from the change bastnasite (Van Wambeke, 1977).

Alteration mineral contained in the Hot Springs area greatly impact to the surrounding environment. Inorganic sulfur is mainly found in the form of sulfate $\left(\mathrm{SO}_{4}{ }^{2-}\right)$ which is the main form of sulfur in waters and soils (Rao, 1992). Sulfur is an element that is essential for living beings, because it is an important element in the protoplasm. Sulfur absorbed by plants in the form of $\mathrm{SO}_{4}{ }^{2-}$, this substance is part of a protein that is present in the form of cysteine, methionine and thiamine. Water-soluble sulfur will soon be absorbed by the roots of plants, because these substances are indispensable plants (especially young plants) on the growth and development beginner (Effendi, 2003). Sulfur in its original form, is a yellow crystalline solid. In nature, sulfur can be found as a pure element or as mineralmineral sulfide and sulfate. Sulfur can kill certain germs or bacteria that attack the skin. But not all skin diseases can be cured only with a soak in the sulfur water baths. That means only a relatively mild skin disease that could be overcome. Springs chloride type generally produce precipitated silica sinter on the surface, while the springs bicarbonate usually produce sinter travel in (Nicholson, 1993). Chloride ion $(\mathrm{Cl})$ is one of 
the major inorganic anions are found in natural waters in an amount more than other halogen anion. High chloride levels, followed by the levels of calcium and magnesium can also lead to the occurrence perkaratan equipment made of metal. Chlorine is often used as a disinfectant to eliminate microorganisms that are not needed, especially for water intended for domestic purposes.

Calcium $(\mathrm{Ca})$ is a mineral element most needed by the body, Cclcium has an important role as a constituent of bones and teeth. Approximately 99\% of the total body consists of calcium. Besides calcium acts as a constituent of cells and tissues. According Piliang (2002), the function of calcium is no less important is as a supplier of nerve impulses from one cell to another. Cole (1988) argued that the waters were poor in calcium is usually too poor content of other ions that are needed by aquatic organisms.

The previous study to interpretation of alteration minerals around the hot springs as Andayany (2015) says that the petrographic analysis to rock samples located at Waiyari geothermal was dominated by feldspathic greywacke. Another mineral alteration types of the rocks in this area are quartz, opaque, lithic, and feldspar minerals. The interpretation of alteration minerals show that the mineral types of the origin rock is sandstone tuff. Petrographic analysis is supported by the XRD method that indicated resources that the alteration minerals present are Generally dominated by the presence of clays such as illitechlorite with particle size of $<0.03 \mathrm{~mm}$, the aboundance of $55 \%$ and the spread evenly.

\section{METHODS}

The primary data in the study area, among others: the measurement of water temperature on the surface, hot water colors and color of alteration rock, and rock samples and sampling rocks at each measurement station.

Analysis of rock samples were calculated using the bulk XRD analysis (analysis of powder and clay analysis or analysis of clay). The results of the analysis form the XRD patterns, will be processed so that the researchers could explain the presence of mineral deposits in the study area. Additionally, rock samples were also analyzed using petrographic methods. The results of the analysis will then be processed by the researchers to determine the value of the speed of mechanical waves propagating in the rock to determine the spread and characteristics of alteration of rocks around the hot springs and reservoirs of geothermal resources in the study area.

The primary data is in the study area, Among others: the measurement of water temperature on the surface, hot water colors and color of rock alteration, and rock samples and sampling rocks at each measurement station.

Analysis of rock samples were calculated using the bulk XRD analysis (analysis of powder and clay analysis or analysis of clay). The results of the analysis form the XRD patterns, will be processed so that the Researchers could explain the presence of mineral deposits in the study area. Additionally, rock samples were Analyzed Also using petrographic methods. The results of the analysis will then be processed by the Researchers to Determine the value of the speed of mechanical waves propagating in the rock to Determine the spread and characteristics of alteration of rocks around the hot springs and reservoirs of geothermal resources in the study area.

\section{RESULTS}

The results of sample analysis identifies a sinter travertine deposition dominated by the presence of the mineral calcium carbonate $(\mathrm{CaCO} 3)$ or calcite in the area around the Tehoru hot springs. Petrographic analysis shows that calcite incision initially preparing amorphous precipitated sinter travertine has been transformed into a microcrystalline calcite size is less than $0.01 \mathrm{~mm}$. Fractures and cavities are formed with a diameter less than $0.3 \mathrm{~mm}$. Some of the void filled by calcite is approximately $0.1 \mathrm{~mm}$. These deposits are massive travertine micritic type and consist of finely crystalline calcite until kriptokristaline. The 
sinter travertine also contains several other minerals were observed through an incision petrographic, ie anhydrite, iron oxides and quartz fragments. Anhydrite generally measuring less than $0.2 \mathrm{~mm}$ and attended by less than $5 \%$. These minerals can be distinguished from calcite based relief and perpendicular her cleavage. Iron oxide present $5 \%$, has the form euhedral, four-square and crowded, and estimated as pyrite. Quartz measuring less than $1.5 \mathrm{~mm}$, anhedral and present less than $5 \%$.

Keterdapatan precipitated carbonate sinter in the Tehoru hot springs area indicate that the rocks underlying the area contains elements carbonate (limestone) at least has occurred assimilation or reaction between the rock-forming elements in the region with a fluid bypass or through it.

The presence of calcium mineral dominant around the Tehoru hot springs a good impact on health is to improve the performance and efficiency of the body for its users.
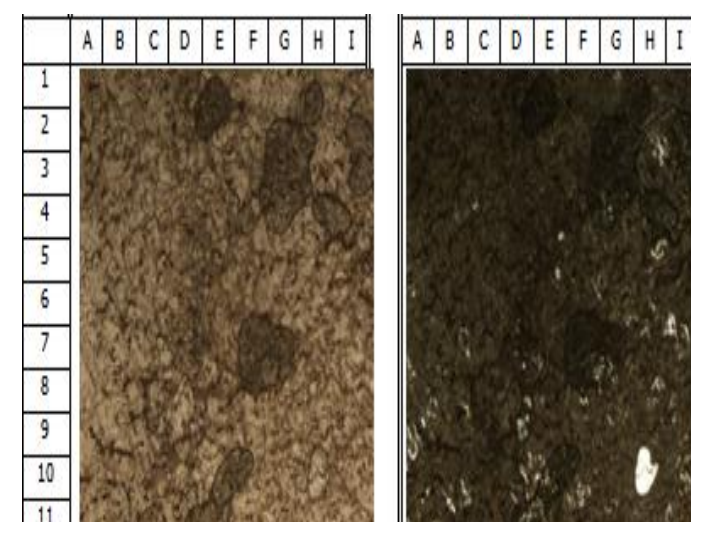

FIGURE 1. The type of alteration mineral (sulfate, calcium carbonate, quartz) around the Tehoru hot springs with petrographic methods

Characteristics of alteration mineral taken from the study Tehoru area hot springs performed using petrographic methods. Petrographic analysis results in Figure 1, show that the rock samples is dominated by calsium carbonat $\left(\mathrm{CaCo}_{3}\right)$. Thus the implication of this research with the presence of alteration minerals dominated by calsium carbonat suggests that the type of hot spring area in Tehoru is a type of reservoir high-temperature, namely $>175^{\circ} \mathrm{C}$, thereby potentially as geothermal field in Central of Moluccas.

\section{CONCLUSION}

The results of sample analysis identifies a sinter travertine deposition dominated by the presence of the mineral calcium carbonate $(\mathrm{CaCO} 3)$ or calcite in the area around the Tehoru hot springs. Petrographic analysis shows that calcite incision initially preparing amorphous precipitated sinter travertine has been transformed into a microcrystalline calcite size is less than $0.01 \mathrm{~mm}$. Fractures and cavities are formed with a diameter less than $0.3 \mathrm{~mm}$. Some of the void filled by calcite is approximately $0.1 \mathrm{~mm}$. These deposits are massive travertine micritic type and consist of finely crystalline calcite until kriptokristaline. The sinter travertine also contains several other minerals were observed through an incision petrographic, ie anhydrite, iron oxides and quartz fragments. Anhydrite generally measuring less than $0.2 \mathrm{~mm}$ and attended by less than $5 \%$. These minerals can be distinguished from calcite based relief and perpendicular her cleavage. Iron oxide present $5 \%$, has the form euhedral, four-square and crowded, and estimated as pyrite. Quartz measuring less than $1.5 \mathrm{~mm}$, anhedral and present less than $5 \%$.

The deposition of sinter travelin form of mineral calcium carbonate or calcite, which is dominant around leave a good impact on the health of which is to improve the performance and efficiency of the body for its users, as a supplier of stimuli nerve from one cell to another and can kill certain germs or bacteria that attack the skin. In addition, sediment sinter travelin soluble in water will soon be absorbed by the roots of plants, because these substances are necessary for plant growth to be around the hot springs.

\section{ACKNOWLEDGMENTS}

A big thank you addressed to the Dean of the Faculty of Mathematics and Natural Sciences University of Pattimura which helps provide funding and research equipment facilities. 


\section{REFERENCES}

1. Andayany, H., 2015, Proceedings 1st International Seminar of Basic Science, Faculty Of Mathematics And Natural Science, Pattimura University, Ambon.

2. Cole, G.A. 1988. Textbook of Limnology. 3th Ed. Waveland Press Inc. Illinois USA.

3. Hefni Efendi, Water Quality Analysis for the management of resources and the aquatic environment, Yogyakarta: canine, 2003), hlm.139.

4. Herman, D.Z. 2006, Geothermal Potential and conservation Thought, Center for Geological Resources, Bandung.

5. Hochstein, M.P. and P.R.L. Browne, 2000, Surface manifestations of Geothermal System with Volcanic Heat Sources, in Encyclopedia of Volcanoes.

6. Henderson, B.C. and R.L. Perry. 1976. Agricultural Process Engineering 3th Edition. The AVI Publishing Company. Inc., Wesport Connecticut. USA.

7. Nicholson, K., 1993. Geothermal fluids. Chemistry and exploration techniques. Springer-Verlag Berlin Heidelberg.

8. Sulaiman, B., Asngari and Nuryasin 2007, Geochemistry of Geothermal Regional Research Akesahu-Tidore, North Maluku, Central Geological Resources, Bandung.

9. Rao, C. S. 1992. Environmental Pollution Control Engineering. Wiley Eastern Limited, New Delhi. 431 p.

10. Tjokrosapoetro, S., E. Rusmana and Suharsono, 2003, Geological Report Sheet Ambon, Maluku, PPPG, Bandung. $32 \mathrm{~h} \mathrm{+}$ geological map scale of 1: 250,000. 